\title{
염료감응태양전지에서 $\mathrm{Pd}$ 촉매층의 전해질과의 반응에 따른 특성 저하 \\ 노윤영 ${ }^{1}$, 송오성 ${ }^{*}$ \\ ${ }^{1}$ 서울시립대학교 신소재공학과
}

\section{Degradation of the Pd catalytic layer electrolyte in dye sensitized solar cells}

\author{
Yunyoung Noh ${ }^{1}$ and Ohsung Song ${ }^{1^{*}}$ \\ ${ }^{1}$ Department of Materials Science and Engineering, University of Seoul
}

요 약 기존 DSSC의 상대전극을 TCO-less로 하여 도전성과 촉매기능을 동시에 가지고 있는 $\mathrm{Pd}$ 의 안정성 확인을 위해 열증착기를 채용하여 유리기판 전면에 $\mathrm{Pd}$ 를 $90 \mathrm{~nm}$ 두께로 증착하고 전해질과의 반응 안정성을 확인하였다. $0.45 \mathrm{~cm}^{2}$ 급 면 적을 가진 glass/FTO/blocking layer/ $/ \mathrm{TiO}_{2} /$ dye/electrolyte $\left(10 \mathrm{mM} \mathrm{LiI}+1 \mathrm{mM} \mathrm{I}_{2}+0.1 \mathrm{M} \mathrm{LiClO}_{4}\right.$ in acetonitrile solution)/Pd/glass 구조의 DSSC 소자를 만들고, 시편제작 1시간, 12 시간 후의 변화를 육안분석, 광학현미경과 FESEM을 이용하여 미세구조 분석을 진행하고, 전기적 분석은 각각 $\mathrm{C}-\mathrm{V}$ (cyclic voltammetry measurements), I-V(current voltage) 분석 을 통해 확인하였다. 미세구조 분석을 통하여 시간이 지남에 따라 확연히 Pd과 전해질이 반응하여 부식되는 것을 확인하 였고, 전기적으로도 시간이 지남에 따라 촉매활동도와 효율이 감소하는 것을 확인하였다. 최종 효율은 1 시간 후에는 $0.34 \%$ 의 광전효율을 보였으나 12 시간 후에는 $0.15 \%$ 를 나타내어 약 $44 \%$ 로 감소하였다. 따라서 염료감응태양전지에 $\mathrm{Pd}$ 촉 매를 채용하기 위해 $\mathrm{I} / \mathrm{I}_{3}{ }^{-}$전해질이 아닌 다른 전해질을 사용하거나 $\mathrm{Pd}$ 전극이 아닌 다른 촉매재를 사용해야 함을 확인하 였다.

\begin{abstract}
A TCO-less palladium (Pd) catalytic layer on the glass substrate was assessed as the counter electrode (CE) in a dye sensitized solar cell (DSSC) to confirm the stability of Pd with the $\mathrm{I}^{-} / \mathrm{I}_{3}{ }^{-}$electrolyte on the DSSC performance. A 90nm-thick Pd film was deposited by a thermal evaporator. Finally, DSSC devices of $0.45 \mathrm{~cm}^{2}$ with glass/FTO/blocking layer/TiO $/$ dye/electrolyte(10 mM LiI $+1 \mathrm{mM} \mathrm{I}_{2}+0.1 \mathrm{M} \mathrm{LiClO}_{4}$ in acetonitrile solution)/Pd/glass structure was prepared. We investigated the microstructure and photovoltaic property at 1 and 12 hours after the sample preparation. The optical microscopy, field emission scanning electron microscopy (FESEM), cyclic voltammetry measurement $(\mathrm{C}-\mathrm{V})$, and current voltage (I-V) were employed to measure the microstructure and photovoltaic property evolution. Microstructure analysis showed that the corrosion by reaction between the Pd layer and the electrolyte occurred as time went by, which led the decrease of the catalytic activity and the efficiency. I-V result revealed that the energy conversion efficiency after 1 and 12 hours was $0.34 \%$ and $0.15 \%$, respectively. Our results implied that we might employ the other non- $\mathrm{I}^{\mathrm{T}} / \mathrm{I}_{3}{ }^{-}$electrolyte or the other catalytic metal layers to guarantee the long term stability of the DSSC devices.
\end{abstract}

Key Words : Dye sensitized solar cell, electrolyte, Pd, thermal evaporation

\section{1. 서론}

최근 심각한 환경오염 문제와 화석 에너지 고갈로 전
세계적으로 에너지 자원의 확보는 각국의 생존 전략과 관련된 문제로 대두되고 있으며, 차세대 신재생 에너지에 대한 중요성이 증대되고 있다. 신재생 에너지 중에서도

본 논문은 2012년도 서울시립대학교 교내학술연구비에 의하여 연구되었음.

"Corresponding Author : Oh-Sung Song(University of Seoul)

Tel: +82-2-2210-2604 email: songos@uos.ac.kr 
태양전지는 무한하며 환경문제를 극복할 수 있어 주목받 고 있다. 최근에는 차세대 태양전지로 각광을 받고 있는 염료감응 태양전지의 연구가 활발하게 진행되고 있다. pn 접합형 구조와 달리, 광전기화학형 구조를 지닌 염료감응 태양전지는 저가이고, $11 \%$ 이상의 에너지 변환효율이 이 미 보고되었다. 또한 앞으로의 효율 향상이 기대되고 있 어 많은 연구가 활발하게 진행되고 있다[1-6].

염료감응 태양전지는 주로 나노결정질 $\mathrm{TiO}_{2}$ 로 이루어 진 작동전극(working electrode), $\mathrm{Pt}$ 로 이루어진 상대전극 (counter electrode), 산화환원작용을 하는 전해질 (electrolyte), 염료(dye)로 구성되어 있다[7].

상대전극은 주로 $\mathrm{I}_{3}{ }^{-}$의 환원과정 속도를 높이기 위해서 전기화학적 촉매 역할을 하는 $\mathrm{Pt}$ 를 코팅한다. $\mathrm{Pt}$ 는 높은 전기전도도를 가지고 있으며 삼요오드(tri-iodide)에 대한 환원작용이 우수하고 다른 전기화학 분야에서도 폭넓게 사용되고 있다. 하지만 고가이며(2012. 현재 \$1402/oz), 염료에 의해 전극표면이 열화되고, 장시간 요오드 전해액 에 접촉하는 경우 소량의 $\mathrm{Pt}$ 가 산화에 의해 용해되어 $\mathrm{PtI}_{4}$ 또는 $\mathrm{H}_{2} \mathrm{PtCl}_{6}$ 등의 요오드화물이 생성되어 촉매기능의 내구성이 떨어지는 단점이 보고되었다.[8, 9] 반면 $\mathrm{Pd}$ 는 백금족 금속 중 가볍고 녹는점이 낮은 금속으로 전성과 연성이 좋고 상대적으로 $\mathrm{Pt}$ 보다 약 $40 \%$ 로 가격이 저렴 하여(2012. 현재 \$576/oz) 백금의 대용으로 쓰일 수 있고, 이미 $\mathrm{Pd}$ 가 $\mathrm{Pt}$ 를 대신하여 자동차 배출가스 정화 촉매 분 야, 화학 공정 촉매 분야, 석유화학 촉매 분야에 성공적으 로 응용된 사례가 다수 보고되었다[10-12].

염료감응 태양전지용 전해질은 $\mathrm{I}^{-} / \mathrm{I}_{3}^{-}$레독스 쌍을 포함 하는 액체 또는 고체 상태의 물질이며, 전해질에 따라서 태양전지의 성능과 장기안정성에 영향을 받게 된다. 액체 전해질에서는 요오드 계의 $\mathrm{I}^{\circ}$ 이온의 소스와 $\mathrm{I}_{2}$ 를 용매에 녹여 생성시키는 $\mathrm{I}_{3}{ }^{-}$와 같은 산화, 환원 종으로 구성되며, 용매로는 acetonitrile과 같은 고극성용매가 사용된다. 지 금까지 보고되고 있는 염료감응 태양전지의 높은 광전환 효율은 거의 대부분은 액체 전해질을 적용하여 얻어진 결과이며, 이러한 액체전해질은 이온전도도가 높고, 전극 에 대한 전기화학적 안정성이 높아야 하며 휘발성이 낮 아야 한다. 그러나 염료감응 태양전지 내에서 기존에 알 려진 것 외의 물질을 채용할 경우 화학적 반응이 일어날 수 있는 문제가 남아있다.

본 연구에서는 $90 \mathrm{~nm}$ 두께의 $\mathrm{Pd}$ 증착을 위해 열증착기 (thermal evaporator)를 사용하였다. 대표적인 PVD(physical vapor deposition)의 방법 중의 하나인 열증착법은 원재료 를 가열하여 VLS(vapor-liquid-solid)과정을 거쳐 증착하 는 방법으로 비교적 공정 변수가 간단하고 기존 스퍼터 링(sputtering)에 대비하여 경제성이 우수하여 채택하였다.
또한 $\mathrm{Pd}$ 촉매층과 acetonitrile solution에 $10 \mathrm{mM} \mathrm{LiI}$, $1 \mathrm{mM} \mathrm{I}_{2}$, and $0.1 \mathrm{M} \mathrm{LiClO}_{4}$ 로 구성되어 있는 전해질과의 반응을 확인하였으며, 촉매 안정성을 보기위해 셀을 제작 한 후 1 시간, 12 시간 후의 촉매활동도와 효율을 비교하였다.

\section{2. 실험방법}

본 연구에서는 열증착(thermal evaporation) 공정을 이 용하여 $\mathrm{Pd}$ 박막을 $90 \mathrm{~nm}$ 두께를 목표로 유리 기판에 증착 하였다. 열증착은 2개의 필라멘트(filament)를 이용하였으 며, 압력 $9.0 \times 10^{-6}$ torr, 증착속도(deposition rate) $1 \mathrm{~A} / \mathrm{sec}$. 조건으로 진행하였다. 상대전극에 $\mathrm{Pd}$ 박막 증착을 위해 $99.99 \% \mathrm{Pd}$ 을 사용하고, 텅스텐 도가니(W crucible)를 이 용하였다.

$\mathrm{DSSC}$ 소자의 작동전극 제작은 glass/FTO 기판에 나노 산화물과의 흡착력 향상과 염료의 정공과의 결합을 억제 하기 위해 스핀코팅 방법으로 블로킹 층(blocking layer) 인 $\mathrm{TiO}_{2}$ 막을 코팅하였다. 이 후 doctor blade 방법으로 $\mathrm{TiO}_{2}$ 산화물 페이스트(paste)를 코팅하여 두께 $8 \mu \mathrm{m}$ 의 $\mathrm{TiO}_{2}$ 필름을 만들고 $0.5 \mathrm{mM}$ cis-vis bis-ruthenium (ㅍ) bis-tetrabutylammmonium(N719)을 흡착시켜 최종적으로 glass/FTO/blocking layer/TiO $/$ dye 의 구조를 갖는 작동전 극을 완성하였다. 위에서 제작한 작동전극과 $\mathrm{Pd}$ 상대전 극을 접합시켜 실링한 후, 전해질 $\left(10 \mathrm{mM} \mathrm{LiI}+1 \mathrm{mM} \mathrm{I}_{2}\right.$ $+0.1 \mathrm{M} \mathrm{LiClO}_{4}$ in acetonitrile solution)을 주입하여 최종 적으로 Fig. 1과 같이 glass/FTO/blocking layer/ $/ \mathrm{TiO}_{2} / \mathrm{dye}$ /electrolyte $/ \mathrm{Pd} / \mathrm{glass}$ 의 수직단면을 가진 유효면적 $0.45 \mathrm{~cm}^{2}$ DSSC 소자를 완성하였다[13].

육안분석을 위해 매크로 사진기(Nikon사 coolpix4500) 를 이용하였다. 또한 $\mathrm{Pd}$ 과 전해질 반응의 표면확인을 위 해 광학현미경을 이용해 100 배율로 확대하여 관찰하였다.

FE-SEM(field emission scanning electron microscope) 을 이용하여 미세구조를 관찰하기 위해 FE-SEM의 메인 챔버에 샘플을 장입하고 $15 \mathrm{kV}$ 가속전압을 사용하여 관 찰하였다.

$\mathrm{C}-\mathrm{V}$ (cyclic voltammetry) 측정으로 촉매활동도(catalytic activity)를 확인하기 위해 세 가지 구성요소로 작동전극, 상대전극 그리고 기준전극 $(\mathrm{Ag} / \mathrm{AgCl})$ 를 이용하였고, $\mathrm{C}-\mathrm{V}$ 곡선은 $\mathrm{CHI} 660 \mathrm{~B}$ 전기화학적인 측정 시스템(sweep condition : $100 \mathrm{mVs}^{-1}$ )을 이용하여 촉매활동도를 확인하 였다.

$\mathrm{I}-\mathrm{V}$ (current-voltage) 광특성 측정은 source measure unit (Keithley model 2400)를 이용하였다. 광원은 $1000 \mathrm{~W} \mathrm{Xe}$ lamp를 사용하였으며 1 sun $\left(100 \mathrm{~mW} / \mathrm{cm}^{2}\right)$ 조건으로 광전 
효율(efficiency)을 분석하였다.

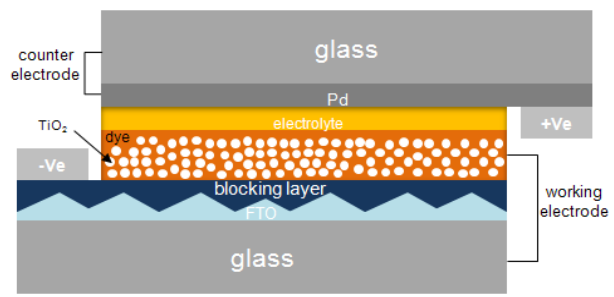

[Fig. 1] The illustration of the DSSC.

\section{3. 실험결과 및 고찰}

Fig. 2는 Pd와 전해질의 반응 전 후의 매크로 이미지 이다. (a)의 좌측이미지는 전해질을 주입한 직후의 이미 지로 $\mathrm{Pd}$ 상대전극이 변화 없이 그대로 유지되고 있으며, 좌측의 표시부을 확대한 우상단 이미지에서도 반응 없이 균일한 $\mathrm{Pd}$ 전극부의 표면을 확인하였다.

(b)의 경우는 시편 제작 후 12 시간이 지난 후의 이미지 이다. 좌측 이미지와 같이 육안으로도 Pd이 전해질과 반 응하여 $\mathrm{Pd}$ 입자들이 박리한 것을 알 수 있었고, 좌측의 표시부을 확대한 우상단의 이미지는 전해질과 반응한 $\mathrm{Pd}$ 필름들이 막대 모양으로 응집하여 부유하는 것을 보였다.

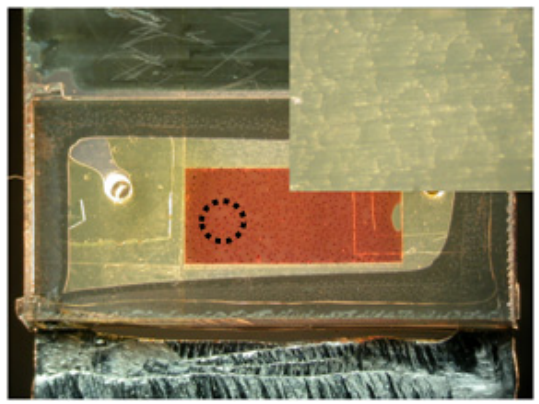

(a)

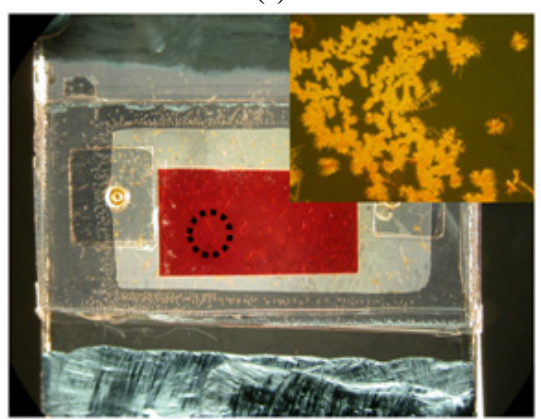

(b)

[Fig. 2] Macro-images of the DSSCs (a) as prepared, and (b) after 12 hours.
Fig. 3은 Pd와 전해질의 반응 전 후의 동일한 배율로 관찰한 광학이미지이다. (a)는 전해질과 반응하기 전의 $\mathrm{Pd}$ 박막의 이미지이다. 검은 불순물을 제외한 전면부에 코팅된 $\mathrm{Pd}$ 의 균질한 박막 표면을 확인하였다. 또한 전해 질과의 반응 안정성을 확인하기 위해 $\mathrm{Pd}$ 전극부를 전해 질 용매인 acetonitrile 안에 침지시킨 경우도 $\mathrm{Pd}$ 전극부에 아무런 반응이 일어나지 않고 (a)와 동일한 이미지를 보 임을 확인하였다.

(b)의 경우 시편제작 후 12 시간이 지난 후의 $\mathrm{Pd}$ 와 전 해질이 반응한 이미지로써 표면 전반부에 $\mathrm{Pd}$ 이 벗겨지고 응집하여 막대 모양를 나타내는 것을 확인하였으며, 이는 앞서 보인 육안 분석과 일치하였다.

따라서 $\mathrm{Pd}$ 의 경우 요오드계 전해질과 반응하여 벗겨 지는 것을 확인하였으며, 이러한 반응은 전해질 용매인 acetonitrile과는 상관이 없이 요오드 성분과의 반응임을 확인하였다.

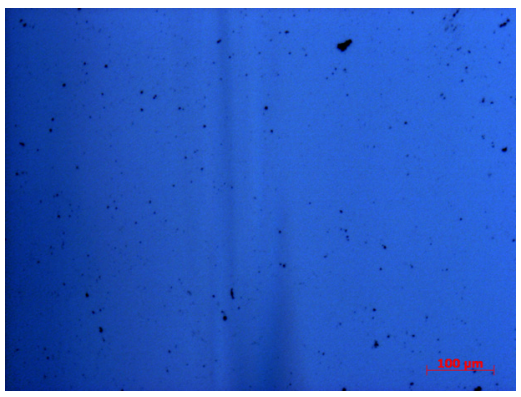

(a)

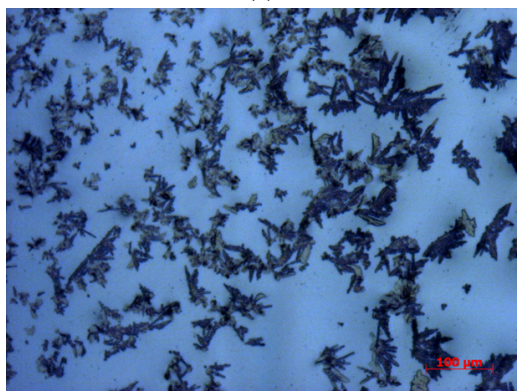

(b)

[Fig. 3] Optical microscopy images of Pd counter electrodes (a)as-prepared, and (b) after 12hours.

Fig. 4는 Pd와 전해질 반응 전 후의 FESEM 결과이다. (a)의 경우 전해질 첨가 전의 Pd 박막의 미세구조를 나타 낸 것으로, 앞서 보인 광학현미경과 같이 검은 점의 불순 물을 확인하였고, 그 외 표면 전반부에 증착된 $\mathrm{Pd}$ 박막을 확인하였다. 우상단에 확대된 그림에서는 전반적으로 크 랙이 보여 불균일한 박막이 형성되었음을 확인하였다. 이 는 열증착기로 증착을 하여 기판과 박막 간의 열팽창계 
수 차이 때문에 나타난 것으로 판단하였다. (b)는 시편제 작 12 시간 이후 $\mathrm{Pd}$ 와 전해질 반응 후의 미세구조를 나타 낸 것으로 $\mathrm{Pd}$ 가 막대 모양으로 형성된 것을 확인하였고, 우상단의 확대된 이미지에서 약 $100 \mu \mathrm{m}$ 크기의 막대모양 으로 응집하는 것을 확인하였다.

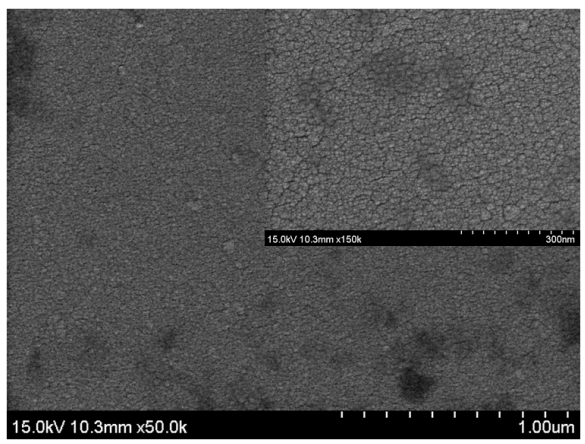

(a)

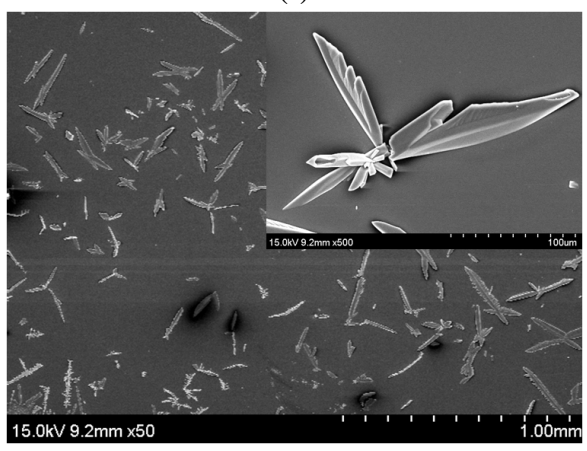

(b)

[Fig. 4] FESEM images of Pd counter electrodes (a) as-preapared, and (b) after 12hours.

Fig. 5는 $\mathrm{Pd}$ 와 전해질의 반응시간에 따른 $\mathrm{C}-\mathrm{V}$ 결과이 다. 비교를 위해 노윤영 등[14]이 보고한 FTO 기판 위에 스퍼터를 이용하여 증착한 $\mathrm{Pd} 90 \mathrm{~nm}$ 전극의 $\mathrm{C}-\mathrm{V}$ 측정 결 과를 나타내었다.

$\mathrm{C}-\mathrm{V}$ 에서 $\mathrm{I}_{3}{ }^{-1} / \mathrm{I}^{-}$산화환원에 따라 두 가지 루프가 나타내 는 것으로 잘 알려져 있다. 우상단의 루프들은 요오드화 물(iodide)이 순차적으로 $3 \mathrm{I}^{-} \rightarrow \mathrm{I}_{3}^{-}+2 \mathrm{e}^{-}$와 $2 \mathrm{I}_{3}{ }^{-} \rightarrow 3 \mathrm{I}_{2}+2 \mathrm{e}^{-}$의 산 화반응을 나타내고, 좌하단의 루프들은 요오드가 $3 \mathrm{I}_{2}+2 \mathrm{e}$ $\rightarrow 2 \mathrm{I}_{3}{ }^{-}$와 $\mathrm{I}_{3}{ }^{-}+2 \mathrm{e}^{-} \rightarrow 3 \mathrm{I}^{-}$로의 환원반응이 일어나는 것을 나타 낸다.

좌하단부의 전류밀도와 전압의 면적을 고려해 볼 때, 반응 12 시간 후의 $\mathrm{Pd}$ 의 촉매활동도는 반응 1 시간 후보다 현저하게 감소하는 것을 확인하였다. 따라서 시간이 지남 에 따라 $\mathrm{Pd}$ 와 전해질의 반응이 계속 진행되어 촉매활동 도에도 영향을 미치는 것을 확인하였다.
한편 0 hour-sputtering은 유리기판 위의 증착된 $\mathrm{Pd}$ 의 경우 전해질과 접촉한 순간 너무 빠르게 반응하여 열화 되기 때문에 좀 더 효율적인 비교를 위해 노윤영 등[14] 이 보고한 동일한 두께의 $\mathrm{Pd}$ 가 스퍼터를 이용하여 FTO 기판에 증착되 상대전극으로 채용된 결과를 이용하였다. 이 $\mathrm{FTO} / \mathrm{Pd}$ 의 경우는 상대적으로 열화 속도가 느려 시편 제작 직 후 측정이 가능하였기 때문이다.

따라서 $\mathrm{Pd}$ 의 경우 상대전극으로 채택할만한 우수한 촉매기능을 가지고 있으나, 이를 채용하기 위해서는 기존 전해질과의 반응성을 고려하여 다른 전해질을 이용해야 함을 확인하였다.

즉, 기존에 $\mathrm{DSSC}$ 의 상대전극 촉매층으로 가능하다고 보고된 $\mathrm{Ru}[15], \mathrm{Ir}$ 등과 같은 백금족과는 달리, $\mathrm{Pd}$ 는 요오 드 전해질과 반응하여 열화된다는 특성을 고려해야 함을 확인하였다.

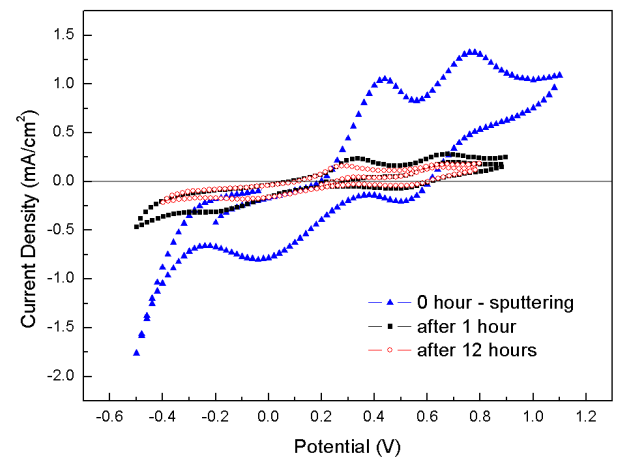

[Fig. 5] The $\mathrm{C}-\mathrm{V}$ for the $\mathrm{Pd}$ counter electrode based on DSSC.

Fig. 6은 $\mathrm{Pd}$ 와 전해질의 반응시간에 따른 $\mathrm{I}-\mathrm{V}$ 결과이 다. 열증착한 $\mathrm{Pd}$ 의 경우, 반응 1 시간 후(12시간 후)의 개 방전압(Voc), 단락전류밀도(Jsc), fill factor(FF) 그리고 에 너지변환 효율은 각각 0.752(0.666), 3.58(3.16), 0.155(0.073), $0.34 \%(0.15 \%)$ 를 나타내어 반응시간이 길어짐에 따라 $\mathrm{Jsc}$, $\mathrm{Voc}, \mathrm{FF}$ 가 감소하여 최종적으로 효율 또한 감소하는 것 을 확인하였다.

한편 앞서 설명한 $\mathrm{C}-\mathrm{V}$ 데이터에서 비교 기준으로 $\mathrm{FTO}$ 기판 위에 스퍼터를 이용하여 $\mathrm{Pd}$ 를 채용한 경우(0 hour-sputter)는 유리기판 시편의 경우 열화속도가 너무 빨라 측정이 불가하여 부둑이 이 시료가 열증착법으로 제조한 $\mathrm{Pd}$ 의 열화되기 전의 특성과 비슷한 정도라고 가 정하여 그림에 같이 표현하였다. 이때의 $\mathrm{Voc}, \mathrm{Jsc}, \mathrm{FF}$ 는 각각 $0.752,9.37,0.656$ 의 특성을 보였고, 에너지변환 효 율은 $4.63 \%$ 로 나타남에 따라 전해질과 반응하여 열화된 열증착 $\mathrm{Pd}$ 보다 전체적으로 매우 우수한 특성을 보였다 
[14].

이는 앞서 보인 $\mathrm{C}-\mathrm{V}$ 결과와 일치하였으며, 이러한 사 실에 근거하여 염료감응 태양전지에 $\mathrm{Pd}$ 를 채용하기 위해 서는 기존 요오드계 전해질이 아닌 전해질을 채용하거나, 다른 기존 촉매와의 안정성이 입증된 촉매층을 채용해야 함을 확인하였다.

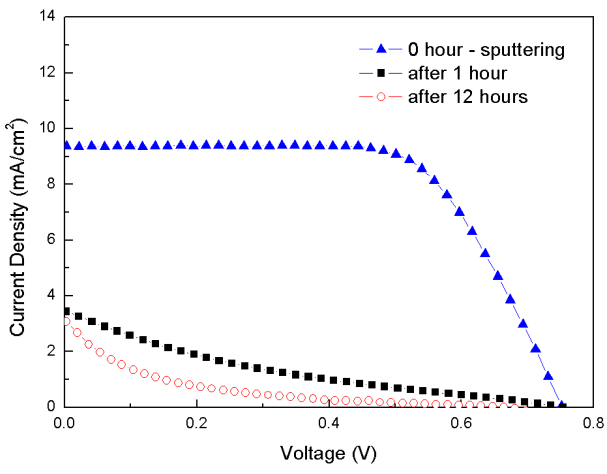

[Fig. 6] I-V characteristic of the Pd counter electrode based on DSSC.

\section{4. 결론}

염료감응형 태양전지의 촉매층으로 적용한 열증착된 나노급 $\mathrm{Pd}$ 박막은 시편제작 후부터 $\mathrm{I}^{-} / \mathrm{I}_{3}^{-}$전해질과 반응하 여 12 시간 이후에는 완전히 기판과 박리되는 문제가 있 음을 확대분석으로 확인하였다. 육안분석과 광학현미경 분석 결과 전해질을 주입한 직후의 $\mathrm{Pd}$ 상대전극은 변화 없이 그대로 유지되고 있었으며, 시편 제작 후 12시간이 지난 후에는 $\mathrm{Pd}$ 입자들이 박리되는 것을 확인하였다. $\mathrm{FESEM}$ 으로 미세구조분석을 한 결과 전해질 첨가 전의 $\mathrm{Pd}$ 박막은 표면 전반부에 생성된 크랙을 확인하였고, 시 편 제작 12 시간 이후에는 약 $100 \mu \mathrm{m}$ 크기의 막대모양으로 박리된 $\mathrm{Pd}$ 을 확인하였다. $\mathrm{C}-\mathrm{V}, \mathrm{I}-\mathrm{V}$ 분석 결과, 이러한 $\mathrm{Pd}$ 층의 분해는 12 시간까지의 시간이 지남에 따라 촉매활동 도의 저하와 최종 광변환효율이 급격히 저하되었다. $\mathrm{DSSC}$ 의 제조에는 이러한 $\mathrm{Pd}$ 층의 특성저하를 고려하여 비 $\mathrm{I}^{-} / \mathrm{I}_{3}{ }^{-}$계의 전해질의 채택 또는 다른 백금계 촉매층의 채용이 필요하였다.

\section{References}

[1] M. Grätzel, "Photoelectrochemical cells", Nature. 414, pp. 338, 2001.
DOI: http://dx.doi.org/10.1038/35104607

[2] J. Chang, et al., "High-performance nanostructured inorganic-organic heterojunction solar cells", Nano Lett. 10, pp. 2609-2612, 2010.

DOI: http://dx.doi.org/10.1021/n1101322h

[3] M. Grätzel, "Conversion of sunlight to electric power by nanocrystalline dye-sensitized solar cells", J. Photochem. Photobiol. A. 164, pp. 3-14, 2004.

DOI: http://dx.doi.org/10.1016/j.jphotochem.2004.02.023

[4] B. O'Regan, et al., "A low-cost, high-efficiency solar cell based on dye-sensitized colloidal TiO2 films", Nature, 353, pp. 737, 1991.

DOI: http://dx.doi.org/10.1038/353737a0

[5] K. Jiang, et al., "Photovoltaics based on hybrdization of effective dye-sensitized titanium oxide and hole-conductive polymer P3HT", Adv. Funct. Mater. 19, pp. 2481-2485, 2009.

DOI: http://dx.doi.org/10.1002/adfm.200900283

[6] K. Kim, et al., "Improvement of electron transport by low-temperature chemically assisted sintering in dye-sensitized solar cell", J. of Photochem. Photobiol. A: Chemistry. 204, pp. 144-147, 2009.

DOI: http://dx.doi.org/10.1021/ic0508371

[7] M. Grätzel, "Solar energy conversion by dye-sensitized photovoltaic cells", Inorg. Chem. 44, pp. 6841-6851, 2005.

[8] E. Olsen, et al., "Dissolution of platinum in methoxy propionitrile containing LiI/I2", Sol. Energy Mater. Sol. Cells. 63, pp. 26-273, 2000.

[9] A. Kay, et al., "Low cost photovoltaic modules based on dye sensitized nanocrystalline titanium dioxide and carbon powder", Sol. Energy Mater. Sol. Cells. 44, pp. 99-117, 1996.

DOI: http://dx.doi.org/10.1016/0927-0248(96)00063-3

[10] K. Kohler, et al., "Highly active palladium/activated carbon catalysts for heck reactions:correlation of activity, catalyst properties, and Pd leaching", Chem. Eur. J. 8, pp. 622, 2002.

DOI: http://dx.doi.org/10.1002/1521-3765(20020201)8:3 $\leq 622::$ AID-CHEM622>3.0.CO;2-0

[11] L. X. Yin, et al., "Carbon-carbon coupling reactions catalyzed by heterogeneous palladium catalysts", Chem. Rev. 107, pp. 133-173, 2007.

DOI: http://dx.doi.org/10.1021/cr0505674

[12] D. Balachari, et al., "Efficient synthesis of 5-aryl-2-vinylfurans by palladium catalyzed cross-coupling strategies", Tetrahedron Lett. 40, pp. 4769-4773, 1999. DOI: http://dx.doi.org/10.1016/S0040-4039(99)00817-5 
[13] G. W. Lee, et al., "Evaluation on over photocurrents measured from unmasked dye-sensitized solar cells", Solar Energy, 84, pp. 418-425, 2010.

DOI: http://dx.doi.org/10.1016/j.solener.2009.12.012

[14] Y. Y. Noh, et al., "Property of palladium counter electrode for dye sensitized solar cells", J. Kor. Inst. Met. \& Mater. in pressed, 2012.

[15] J. J. Han, et al., "Effect of the Thickness of the Ru-coating on a Counter Electrode on the Performance of a Dye-sensitized Solar Cell", J. Kor. Inst. Met. \& Mater. in pressed, 2012.

\section{송 오 성(Oh-Sung Song)}

[정회원]

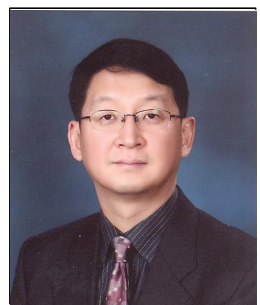

- 1987년 2월 : 서울대학교 금속공 학과 (공학사)

- 1988년 2월 : 서울대학교 금속공 학과 (공학석사)

- 1994년 5월 : MIT 재료공학 (공 학박사)

- 1996년 3월 : NTT 기초연구원

- 1997년 8월 : 삼성전자 CPU 기 술팀

- 1997년 9월 현재 : 서울시립대학교 신소재공학과 교수

<관심분야>

태양전지, 반도체재료, 자성재료, 주얼리 소재

\section{노 윤 영(Yun-Young Noh)}

[정회원]

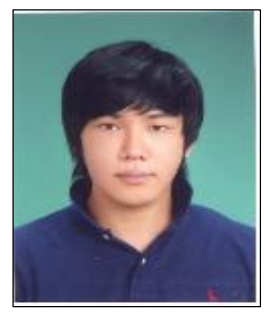

- 2011년 2월 : 충남대학교 재료공 학과 (공학사)

- 2011년 3월 현재 : 서울시립 대학교 신소재공학과 석·박사 통합과정

<관심분야>

태양전지 